Florida International University FIU Digital Commons

\title{
The bass as a melodic voice in jazz : extended program notes for thesis recital
}

\author{
Mark Curtis Beverley \\ Florida International University
}

DOI: $10.25148 /$ etd.FI14051135

Follow this and additional works at: https://digitalcommons.fiu.edu/etd

Part of the Music Performance Commons

\section{Recommended Citation}

Beverley, Mark Curtis, "The bass as a melodic voice in jazz : extended program notes for thesis recital" (2010). FIU Electronic Theses and Dissertations. 1631.

https://digitalcommons.fiu.edu/etd/1631 
FLORIDA INTERNATIONAL UNIVERSITY

Miami, Florida

THE BASS AS A MELODIC VOICE IN JAZZ:

EXTENDED PROGRAM NOTES FOR THESIS RECITAL

A thesis submitted in partial fulfillment of the

requirements for the degree of

MASTER OF MUSIC

by

Mark Curtis Beverley 
To: Acting Dean Brian Schriner

College of Architecture and the Arts

This thesis, written by Mark Curtis Beverley, and entitled The Bass as a Melodic Voice in Jazz: Extended Program Notes for Thesis Recital, having been approved in respect to style and intellectual content, is referred to you for judgment.

We have read this thesis and recommend that it be approved.

Michael Orta

Karen Fuller

Gary Campbell, Major Professor

Date of Defense: March 22, 2010

The thesis of Mark Curtis Beverley is approved.

Acting Dean Brian Schriner
College of Architecture and the Arts

Florida International University, 2010 


\author{
ABSTRACT OF THE THESIS \\ THE BASS AS A MELODIC VOICE IN JAZZ: \\ EXTENDED PROGRAM NOTES FOR THESIS RECITAL \\ by \\ Mark Curtis Beverley \\ Florida International University, 2010 \\ Miami, Florida \\ Professor Gary Campbell, Major Professor
}

This thesis discusses the use of the bass as a melodic instrument in jazz. It focuses on seven compositions performed for a Master's recital on March 22, 2010. For each selection, I provide a brief biography of the composer, information about the song and insight on performance practice. I examine the advanced techniques pioneered by innovative bassists and explore ways in which they can be used to further exploit the melodic potential of the bass in a jazz context. A compact disc recording of the recital is included. 


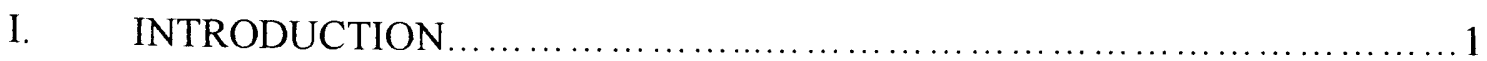

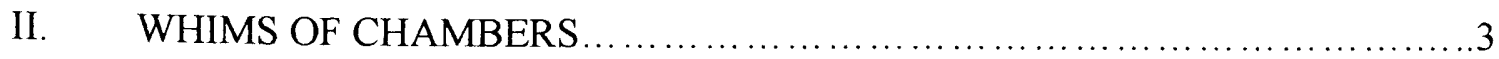

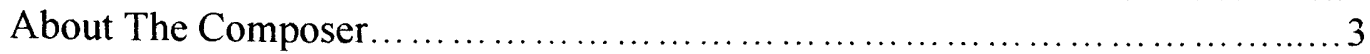

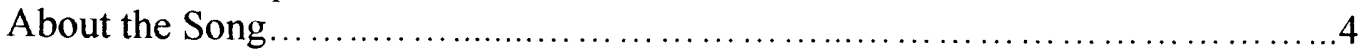

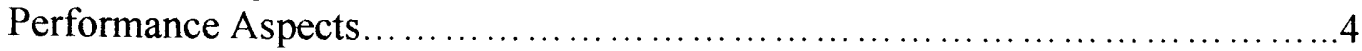

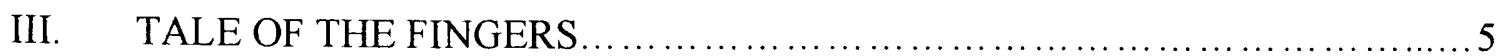

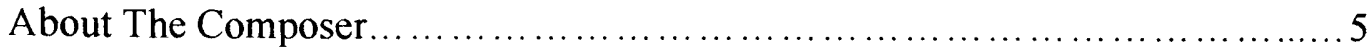

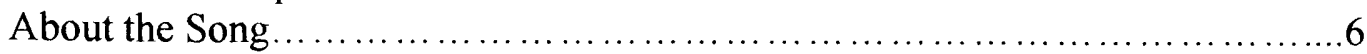

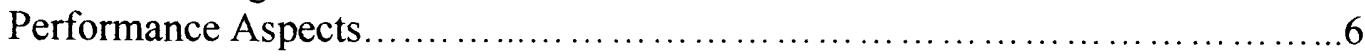

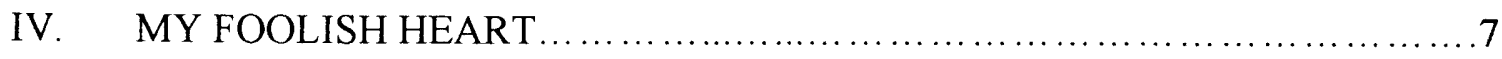

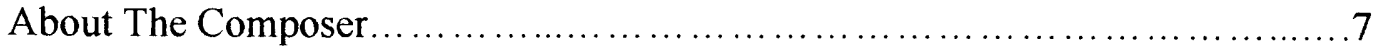

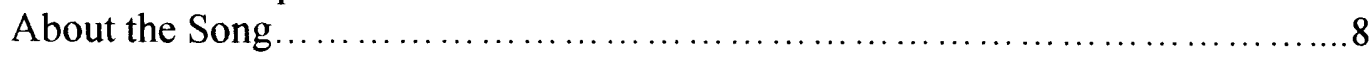

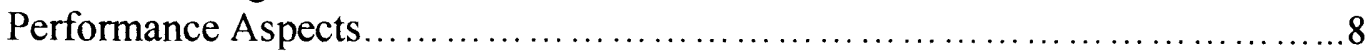

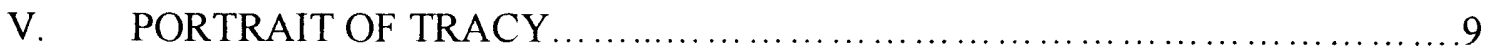

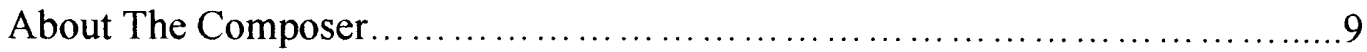

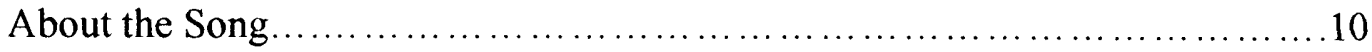

Performance Aspects.............................................. 10

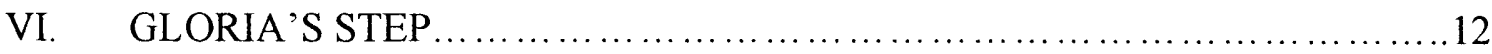

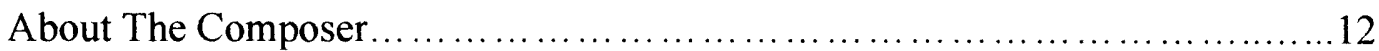

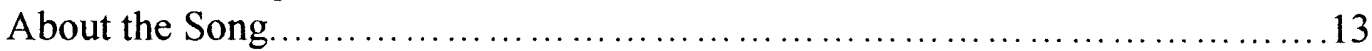

Performance Aspects.................................................. 13

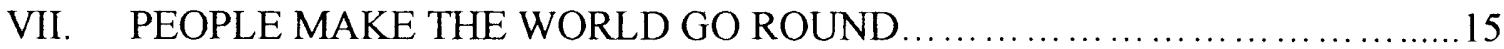

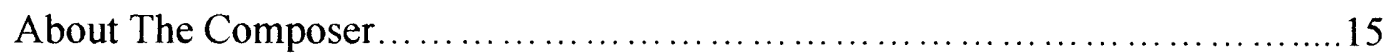

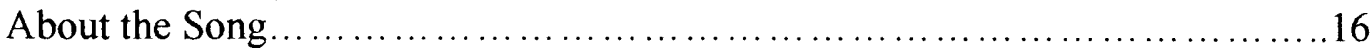

Performance Aspects............................................... 17

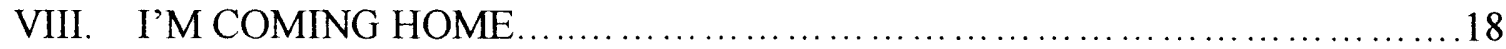

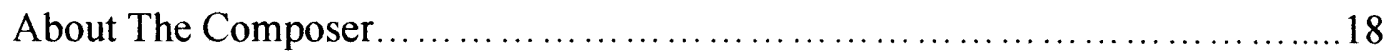

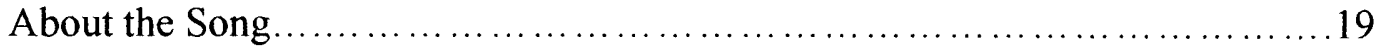

Performance Aspects................................................. 19

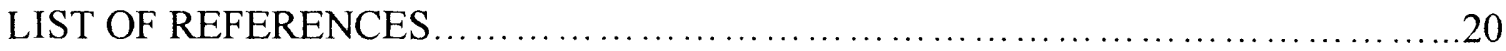




\section{INTRODUCTION}

Throughout the twentieth century, the role of the bass instrument in jazz has been expanded significantly. Originally, the bass was used to provide rhythmic support for the melody instrument or soloist in jazz music. The main function of the bass was to provide a rhythmic pulse while outlining the harmonic movement (chord changes) of a song. This began to change when certain innovators revealed the melodic potential of the bass in a jazz setting. This evolution began with the "father of modern jazz bass playing", Jimmy Blanton (Coolman 1985, 3). After he passed away in 1939, at the young age of 23 , his legacy was carried forth by the next generation of bassists, who continued to develop the role of the bass in jazz.

Most of my recital focused on the compositions of Blanton's successorsspecifically Paul Chambers, Scott LaFaro and Jaco Pastorius. With regard to developing the bass as a melodic instrument in jazz, these three bassists were the most influential in their respective eras. All three were prolific soloists who employed melodic devices atypical for bassists of their time. All of them had a lyrical approach to soloing that employed horn-like phrasing.

These bassists pushed the limitations of their instruments technically. Chambers did this by playing many of his solos arco (using the bow). While this is standard in classical music, this was unique in the jazz idiom. LaFaro exploited the upper register (thumb position) of the double bass more than any other jazz bassist before him. While 
Pastorius pioneered numerous techniques on the fretless electric bass, I concentrate on his use of harmonics as featured in his composition "Portrait of Tracy".

In this paper I analyze the innovative bass techniques introduced by these past masters; performed on my Master's recital and documented on the accompanying compact disc, I employ some of the techniques used by these seminal bassists. In an attempt to develop a more lyrical voice for the double bass, I emphasize bowing in most of the selections, often in the upper octave of the instrument. In such situations, the use of harmonics (one of Pastorius's innovations) is very effective at ensuring sound intonation. By combining the different techniques of these key innovators, my recital presents the bass as a melodic voice in jazz. 


\section{WHIMS OF CHAMBERS}

\section{ABOUT THE COMPOSER}

Paul Laurence Dunbar Chambers (better known as Paul Chambers or, simply, P.C.) was born in Pittsburgh on April 22, 1935. Following the death of his mother, he moved to Detroit, where he began playing music. He began playing the baritone horn and tuba before taking up the double bass in 1949. During his formative years, he received some classical training from a bassist in the Detroit Symphony Orchestra. He further developed his bowing skills while performing with a classically inspired group called the Detroit String Band. While attending Cass Technical High School from 1952 to 1955 , Chambers played with the school symphony, among other groups.

His early musical training helped to define his style in a number of ways. His background as a horn player laid the foundation for Chambers to become a lyrical soloist: it gave him a melodic vocabulary and the ability to phrase in a vocal fashion. As a vocalist, or horn player, the need to breathe plays a role in determining phrase lengths. On certain recordings, Paul can be heard breathing in between solo phrases. Two of Chambers's biggest influences, Ray Brown and Oscar Pettiford, can be heard doing the same thing on many recordings. Another huge influence for Paul was the great Leroy "Slam" Stewart, who played all of his solos arco while singing them an octave higher. As a horn player, this manner of phrasing came naturally to P.C. 


\section{ABOUT THE SONG}

"Whims of Chambers" is a twelve-bar blues in the key of F featured on Paul Chambers's eponymous debut album as a leader on the Blue Note Label. It is a simple, be-bop style head that is played by the guitar (Kenny Burrell) and the bass (Chambers) with the drummer (Philly Joe Jones) accompanying them using brushes. The melody is played twice, as is standard for a blues head, before the solo section. It is performed at a medium tempo (approximately 160 beats per minute) that accommodates a relaxed swing.

\section{PERFORMANCE ASPECTS}

After playing the melody in the original register, I perform it up an octave (in thumb position) in order to accentuate the lyrical quality of the melody and to create a contrast between the repeated melody statements. Although performing the interval of a fourth in thumb position on the double bass presents a special technical issue (Morton 1991, 57), the melody sits comfortably in the upper octave, largely because Paul Chambers played it primarily in the lowest position using many open strings. In thumb position (one octave higher), the original open strings easily lend themselves to octave harmonics.

While Paul Chambers plays the melody pizzicato (plucked with the fingers) on the original recording of "Whims of Chambers," I perform it arco on the final melody statement. The gritty sound of the bowed bass complements the bluesy quality of the melody. This reintroduces the theme with a new timbre. 


\section{TALE OF THE FINGERS}

\section{ABOUT THE COMPOSER}

Paul Chambers was the "most recorded bassist in jazz between 1955 (when he moved to New York) and 1962" (Coolman 1985, 36). After moving to New York, Chambers soon attracted the attention of trumpeter Miles Davis. Davis hired him to play in his highly influential quintet in 1955, shortly before Paul's twentieth birthday. This high profile gig made P.C. an in-demand sideman for recording sessions and gave him the opportunity to record as a leader, which was rare for a bassist at this time. Chambers recorded on many of the classic albums of this era with prominent artists; besides Miles Davis, they included John Coltrane, Lee Morgan, Thelonious Monk, Wes Montgomery and Sonny Rollins among others.

Paul Chambers was unique in that he was equally adept at soloing arco or pizzicato. This was one of several musical attributes that brought him a great deal of recognition from bassists and other instrumentalists. The other bassists of this epoch who would dare to solo with the bow could easily be counted on one hand! It was particularly impressive considering that Paul used gut strings, which are particularly difficult to play with the bow. Without any amplification, Chambers would cleanly bow solos at the fastest tempi with a relaxed swing feel. 


\section{ABOUT THE SONG}

There is no better testament to Paul's prowess with the bow than "Tale of the Fingers." It is a be-bop head performed $\operatorname{arco}$ at a fast tempo (approximately 230 beats per minute). While his is a particularly brisk tempo for a double bassist to play swing eighth-notes (especially with the bow), Paul Chambers maintains a consistent swing manner throughout. Following the melody statement, accompanied by piano and drums, Paul improvises three brilliant choruses over the 32-bar song form. Even by modern standards, "Tale of the Fingers" is a singular tour de force of bowed bass in jazz.

\section{PERFORMANCE ASPECTS}

My main goal in the performance of this melody is have it sound clean, with a pleasant tone, clear articulation and a relaxed swing. In order to achieve this, the tempo is relaxed slightly (down to approximately 180 beats per minute). Although Chambers plays closer to the frog of the bow (in order to produce more volume), I play closer to the tip to produce a cleaner, more articulate sound. Additionally, using less bow produces a less scratchy tone. 


\section{MY FOOLISH HEART}

\section{ABOUT THE COMPOSER}

Victor Young (August 8, 1900-November 10, 1956) started out in classical music as a concert violinist, before branching out into popular music. In the latter half of the 1920s, he began playing and arranging for the Ted Fio Rito Orchestra, thus inaugurating his crossover into the realm of popular music. He later joined the orchestra of Isham Jones as a violinist and arranger. In 1930, he arranged the Hoagy Carmichael tune "Stardust" as a sentimental ballad featuring himself as a soloist. His arrangement became the first of many hit versions of this song, which would be recorded by dozens of artists in different genres.

In the wake of his success with the Isham Jones Orchestra, Victor Young was signed to Brunswick records in 1931. Until 1934, Young had many of the top jazz musicians in New York City playing for his studio sessions, recording dance music intended for radio play. In 1934, he signed with Decca records and continued recording in New York until the mid-1930s.

In 1936, he relocated to Hollywood, California to concentrate on making music for films, writing there until his death in 1956 . He wrote the scores for over fifty movies and worked with prolific vocalists such as Bing Crosby and Judy Garland. During this period, he penned such classics as "Stella by Starlight" and "When I Fall in Love" (songs that have been recorded countless times by jazz musicians). He was nominated for twenty-two Oscars (won one) and was awarded a Golden Globe Award and an Emmy. 


\section{ABOUT THE SONG}

"My Foolish Heart" was, originally, the theme song from a 1949 film bearing the same title. The film was based loosely on a short story by J.D. Salinger entitled "Uncle Wiggily in Connecticut." Much to the chagrin of Salinger and the film-makers, the critics offered scathing reviews of the film. Despite the film's lack of commercial success, the title song, sung by Martha Mears, was nominated for Best Song in the music category at the Academy Awards.

Although various singers recorded the song with some success, it was Billy Eckstein's version that made it famous. After Eckstein's recording sold over a million copies, the song would be interpreted by vocalists Frank Sinatra, Tony Bennett and Tom Jones, to name a few. Among numerous others, Bill Evans recorded an instrumental version with his celebrated trio that included bassist Scott LaFaro and drummer Paul Motion. Today, the song remains a jazz standard from the great American songbook.

\section{PERFORMANCE ASPECTS}

I perform the melody arco accompanied by piano and drums, played with brushes. On the first melody statement, I perform the melody in the lower octave with a lush vibrato. For the solos, the rhythm section plays in the style of the Bill Evans trio, employing a loose, broken-time feel. I play the restatement of the melody pizzicato and an octave higher, with a wide vibrato. My intention was to emulate a vocalist in interpreting this beautiful melody. 


\section{PORTRAIT OF TRACY}

\section{ABOUT THE COMPOSER}

"Jaco" was born John Francis Pastorius III on December 1, 1951 in Norristown, Pennsylvania. By 1959, the Pastorius family had relocated to Oakland Park—a suburb of Fort Lauderdale, Florida. Jaco's father was an entertainer who sang and played drums. Following in his father's footsteps, Jaco took up the drums at the age of twelve. Also a talented athlete, Jaco broke his wrist at the age of thirteen, an accident that prohibited him from playing the drums (Milkowski 2005, 11).

Because of this injury, Jaco learned instead to play the electric bass, progressing rapidly by dint of voracious practice, despite any formal training. Before long, Jaco was playing bass professionally, with various units in the South Florida area. He played in numerous styles but, his main interests were $R \& B$ and jazz music. Jaco refined his chops while maintaining a busy gigging schedule.

In 1972, Jaco landed a gig with Wayne Cochran and the C.C. Riders- a white soul revue based out of South Florida. While touring with them, Jaco learned to read and write music, while studying theory and arranging with the older, more experienced members of the band. Simultaneously, Jaco developed his playing style by performing five-hour gigs every night while practicing on the tour bus (Milkowski 2005, 40).

While on tour with Cochran, he also created the instrument that would define his signature sound. Jaco decided that he wanted a fretless electric bass, so he used a pair of pliers to remove the frets from a Fender bass belonging to one of his band mates 
(Milkowski 2005, 44). Jaco pioneered the use of the fretless electric bass and was responsible for making it famous.

In 1976, Jaco Pastorius released his self-titled solo debut as a leader. It showcased his impressive, innovative techniques. Additionally, other than a rendition of Charlie Parker's "Donna Lee," all of the songs on the album were his original compositions. According to bass historian Jim Roberts (2001, 129), Jaco's first solo album is "the single most important and influential solo recording ever made by an electric bassist."

\section{ABOUT THE SONG}

"Portrait of Tracy," from Jaco's self-titled debut is an ode to his first wife, Tracy. It was performed using harmonics on fretless electric bass, without any accompaniment. Such an extensive use of harmonics on electric bass was revolutionary. Typically, harmonics were only used for tuning the instrument. While harmonics are commonly used in the classical double bass solo literature (the Dragonetti Concerto in G-major is a well-known example), they had never been used so extensively on the electric bass. Jaco combined harmonics with standard, fingered notes to create a beautiful piece for solo electric bass.

\section{PERFORMANCE ASPECTS}

For the performance of this piece, I try to emulate the composer's technique (ascertained by carefully viewing video footage of Pastorius). Jaco plucks the strings extremely close to the bridge in order to make the harmonics more articulate and clear. 
When playing harmonics on two adjacent strings simultaneously, Jaco rakes both notes with one finger rather than using two separate digits. This makes the harmonics sound more resonant. In some passages, he uses his thumb to play fingered notes on the low Estring, while using the aforementioned technique to play harmonics on the high strings.

I use an alternate fingering for the Eb harmonic that occurs numerous times throughout the piece. Pastorius's fingering involves a large stretch that is very uncomfortable to execute for a player without very long fingers. Instead, I use an artificial harmonic, produced by stopping the string with my right thumb, two octaves above the fingered note, while plucking the string with the right index finger. 


\section{GLORIA'S STEP}

\section{ABOUT THE COMPOSER}

Scott LaFaro (April 3,1936-July 6, 1961) made a significant impact on playing the double bass in jazz during his regrettably short lifetime. LaFaro grew up in a musical family in New Jersey, where he began studying piano. He later took up the bass clarinet and then switched to the tenor saxophone in high school. At the age of seventeen, LaFaro started playing the double bass in order to fulfill a college requirement to play a string instrument (LaFaro-Fernandez 2009, 50).. After three months at Ithaca College, Scott settled on the bass as his instrument of choice.

During his Sophmore year, LaFaro became proficient on the bass and left College to join a jazz big band led by trombonist Buddy Morrow. After a tour across the country, he left Morrow's band and moved to Los Angeles to freelance. He was very successful there, playing and recording with the likes of Victor Feldman, Cal Tjader, Stan Kenton and Chet Baker.

In 1959, he joined with pianist Bill Evans and drummer Paul Motion to form one of the most influential trios in the history of jazz. This trio was known for interaction that blurred the distinction between the soloist and accompanist. They explored very slow ballad tempos and low dynamic levels that hitherto had been uncommon in jazz. In 1960, he played on Ornette Coleman's revolutionary album Free Jazz: A Collective Improvisation. 
Unfortunately, LaFaro died in a car accident at age of twenty-five. Despite his early death, he made an enormous contribution to jazz with his unconventional method of playing, both as a soloist and as an accompanist. His successor in the Bill Evans trio commented: "He was so technically ambitious that he raised the bar for everyone. No one since Jimmy Blanton had set such a high standard" (LaFaro-Fernandez 2009, 157).

\section{ABOUT THE SONG}

Gloria's Step was one of Scott LaFaro's two completed compositions. The title refers to his girlfriend Gloria Gabriel, a dancer for Dick Haymes. LaFaro's roommate, pianist Don Friedman, recounted that "when he (Scott) was practicing in their apartment, he'd always listen excitedly for Gloria's step coming up the stairs" (LaFaro-Fernandez $2009,113)$. While many thought that the title was a reference to Gloria's dancing, this is not the case, according to Friedman.

The structure of the song is unusual for a jazz tune. The form is twenty bars long. It begins with a repeated five-bar phrase. The following ten bars contain a series of six half-diminished seventh chords that move in an unconventional manner. Don Friedman noted that LaFaro was "very interested" in this type of chord and believes that "Gloria's Step" was an "outgrowth of his interest in those chords" (LaFaro-Fernandez 2009, 100).

\section{PERFORMANCE NOTES}

This is an exercise in playing in the style of Scott LaFaro, when performing in the Bill Evans trio. As an accompanist, the bass is free to depart from a strict walking bass line to interact with the soloist. The time is often implied rather than played explicitly by 
the bass. LaFaro was known for using quarter-note triplets and playing both straight and swung eighth-notes within a single solo. He used these devices throughout the range of the instrument, exploiting the middle and upper registers of the bass extensively. LaFaro would often start a phrase in the lower register and finish it in the upper register. I use all of these devices in emulating Scott LaFaro's innovative style. 


\section{PEOPLE MAKE THE WORLD GO ROUND}

\section{ABOUT THE COMPOSER}

Thom Bell was born to a musical family in Kingston, Jamaica on January 26, 1943. Encouraged by his family, Bell had already begun playing the drums at the age of four. By the time he was five, his family had relocated to Philadelphia, where Thom began studying piano. He continued his studies and played classical piano recitals throughout his formative years. At the age of seventeen, Bell teamed up with Kenny Gamble as part of Tommy and Kenny, a singing and songwriting duo. Although they did not achieve much success at this time, they would collaborate years later to produce dozens of hit records.

Bell relocated to New York where he hoped to become a conductor on Broadway. Despite a superlative test performance in I961, Bell was told that there was no work for "his kind"- a person of color- on Broadway (Jackson 2004, 17). Giving up his dreams of becoming a Broadway conductor, Bell got a job playing piano at Harlem's Apollo Theater. Disillusioned, he soon returned to Philadelphia, where he became a member of the house band at the Uptown Theater.

In 1967, Bell got his first gig as a writer/producer at Cameo Records. While working for Cameo, Bell met the Delfonics, the singing group with whom he would produce his first hit single. For the Delfonics, Bell wrote and produced "La La Means I Love You" (1968) and the Grammy award-winning "Didn't I Blow Your Mind This 
Time" (1970). On these early recordings, which featured lush orchestrations with intricate string arrangements, Bell laid the groundwork for the sound of "Philly Soul."

In 1971, Bell left the Delfonics and teamed up with Avco Records to produce the Stylistics (another Philadelphia-based singing group). He built the group around the nasal tenor falsetto of Russel Thompkins Jr. using orchestration techniques similar to those that he pioneered with the Delfonics (Jackson 2004, 104). Their 1971 self-titled debut album, produced entirely by Thom Bell, was a huge success, yielding five hit songs.

\section{ABOUT THE SONG}

"People Make The World Go Round" exemplifies Thom Bell's compositional genius. Aside from the lush orchestration, the verse is built around a catchy ostinato figure played by the bass and electric piano. A marimba outlines the harmony, playing three-note voicings that form a rhythmic counterpoint to the ostinato. Throughout the verses, the memorable melody fits snuggly within this rhythmic vamp. The original version features glockenspiel, string swells and other effects that defined Bell's signature sound.

Although the song is in standard $4 / 4$ meter, Bell smoothly incorporates odd-time measures throughout the piece. The verse and the chorus both have bars of $2 / 4$ within the song structure. Furthermore, the vamp at the end of the song alternates between one-bar of $4 / 4$ followed by a bar of $5 / 4$. While this is unconventional, it flows seamlessly. 


\section{PERFORMANCE ASPECTS}

In an attempt to emulate Thompkins' delicate falsetto, I perform the melody arco in the upper register of the bass. To preserve the lyrical quality of the melody, I perform it almost entirely on one string (the high G-string). The one note that I play on the Dstring is an A-natural harmonic, which I use to help ensure precise intonation.

The solo section incorporates the verse ostinato. This is a perfect vehicle for modal improvisation. Similar to the Miles Davis classic "So What," the vamp is based on the Dorian mode, a favorite for Jazz improvisation. Each soloist cues the chorus at the end of his solo to create harmonic tension and release and to end each solo with the melodic hook of the song. The odd-time vamp at the end of the tune (alternating bars of $4 / 4$ and $5 / 4$ meter) features the drummer in a rhythmically interesting context. 


\section{I'M COMING HOME}

\section{ABOUT THE COMPOSER}

After his success with the Stylistics, Thom Bell became better known in the music world. Seeking new projects, he decided to write and produce an album for Johnny Mathis. While this might seem like an unlikely pairing, Bell had long idolized Mathis for his "fantastic voice" (Jackson 2004, 142). Clive Davis, then president of Columbia records (Mathis' record label), felt that this partnership was a mismatch and opposed the collaboration. At this time, Mathis had reached a low point in his career- he was not getting played on black or white radio stations. Mainly for this reason, Davis allowed them to make an album together despite his initial reluctance. Bell had finally overcome the racial barriers that had previously limited his career options.

Although the album I'm Coming Home was not a huge commercial success, it was a positive collaboration for both Bell and Mathis. Mathis himself said that it was "one of the best albums I've ever done" (Jackson 2004, 143). This is significant, considering that Mathis made over eighty albums throughout his career! Bell had the opportunity to write and produce for one of his heroes, subsequently touring with Mathis, as his arranger and conductor. Although Bell was adamant in doing all new material, Mathis requested to remake two of the songs that Bell had written for the Stylistics: "Stop, Look and Listen (to Your Heart)" and "I'm Stone in Love with You." Philadelphia soul singer Teddy Pendergrass later used a song from I'm Coming Home, "Life is a Song Worth Singing," on his 1978 record bearing the same title. 


\section{ABOUT THE SONG}

Although "I'm Coming Home" was written for Johnny Mathis, the Spinners, another R\&B group produced by Thom Bell, had more commercial success with the song than did Mathis. The Spinners's version featured a lively beat, driven by a gospelinspired piano riff (played by Bell) and conga drums. Additionally, it was infused with Bell's signature sound: smooth horn arrangements, lavish strings and well-conceived vocal harmonies.

Additionally, Philadelphia bassist Christian McBride recorded an instrumental version on his 1998 record A Family Affair. This version features an even livelier rhythm than the Spinners version! The foundation is a "second-line" rhythm (also called "Bo Diddley beat") that is essentially a traditional New Orleans style based around a 3-2 clave pattern.

\section{PERFORMANCE ASPECTS}

The performance will be based on Christian McBride's interpretation of "I'm Coming Home". The tenor saxophone performs the melody accompanied by a percolating rhythm section consisting of drums, bass and electric piano. The bass solo will be performed arco, in the style of McBride, rife with vocally-inflected, bluesinspired riffs. 


\section{LIST OF REFERENCES}

Coolman, Todd. 1985. The Bass Tradition: Past, Present, Future. New Albany: Jamey Aebersold Press.

Jackson, John A. 2004. A House on Fire: The Rise and Fall of Philadelphia Soul. New York: Oxford University Press.

LaFaro-Fernandez, Helene. 2009. Jade Visions: The Life and Music of Scott LaFaro. Denton: University of North Texas Press.

Milkowski, Bill. 2005. Jaco: The Extraordinary and Tragic Life of Jaco Pastorius. San Francisco: Backbeat Books.

Morton, Mark. 1991. Dr. Morton's Double Bass Technique: Concepts and Ideas. Lubbock: Basso-Profundo Publications.

Roberts, Jim. 2001. How The Fender Bass Changed the World. San Francisco: Backbeat Books. 